\title{
Behandling ved psykogene ikke-epileptiske anfall
}

\author{
Den viktigste differensialdiagnosen til epilepsi hos unge voksne er \\ psykogene ikke-epileptiske anfall. Slike anfall kan ytre seg svært for- \\ skjellig, og det er som regel sammensatte bakenforliggende årsaker. \\ Optimal behandling av de rammede fordrer tett samarbeid mellom \\ nevrologien og psykiatrien.
}

Psykogene ikke-epileptiske anfall (psychogenic, non-epileptic seizures, PNES) er epilepsiliknende anfall som ikke skyldes epilepsi. Dette er den viktigste differensialdiagnosen til epilepsi hos ungdom og voksne $(1,2)$.

\section{Etiologi}

Etiologien er kompleks. Man antar at både psykogene faktorer (angst, dissosiasjon, ikke-dissosiativt posttraumatisk stress, seksuelt misbruk, personlighetsavvik, mellommenneskelige vansker, sosiale og familiære problemer) og somatiske faktorer, som kronisk sykdom eller utviklingshemning, kan spille en rolle.

Utformingen av anfallene varierer. Psykogene ikke-epileptiske anfall kan likne alle typer epileptiske anfall, fra korte fjernhetsepisoder til store krampeanfall. Ofte varer imidlertid disse anfallene lenger enn epileptiske anfall, som gjerne er over etter 1-2 minutter. Tilstanden kategoriseres under konversjonslidelser eller dissosiative tilstander, eventuelt som «andre uspesifiserte kramper» innen ICD- og DSM-systemet.

Tilstanden kan forstås som «en atferdsmessig respons på psykisk, fysisk eller sosial belastning karakterisert ved et midlertidig tap av kontroll» (2). Mange rammede har levd med en epilepsidiagnose $\mathrm{i}$ en årrekke og har brukt antiepileptiske legemidler. Man regner at rundt $20 \%$ av dem som henvises til epilepsisentre for behandlingsrefraktær epilepsi, har psykogene ikkeepileptiske anfall (3). At anfallene viser seg $i k k e$ å være ledd $\mathrm{i}$ epilepsi, kommer overraskende på mange.

Pasientgruppen er svært heterogen. Tilstanden ses hyppigst hos unge jenter, men forekommer hos begge kjønn og i alle aldre. Mange faller ut av skole og arbeidsliv. Psykiatrisk komorbiditet er vanlig, og det antas at kun $5 \%$ av dem med psykogene ikke-epileptiske anfall $i k k e$ har en komorbid psykiatrisk lidelse (1).

\section{Diagnostikk}

Diagnostikk av anfallslidelser kan være utfordrende, det krever både kunnskap og erfaring. En studie viste at det i gjennomsnitt gikk sju år fra anfallsdebut til diagnosen ble stilt (4). Selve gullstandarden i diagnostikken er registrering av anfallene ved videotelemetri, sammenholdt med anamnesen. Atypisk anfallsutforming kombinert med manglende epileptiform aktivitet i EEG under anfall styrker mistanken. Imidlertid kan også enkelte epileptiske anfall, særlig fokale anfall med bevart bevissthet og noen anfall som utgår fra frontallappen, også opptre uten EEG-korrelat.

En grundig sykehistorie med komparentopplysninger, med særlig vekt på anfallene (utforming, omstendigheter, frekvens, varighet) og psykososiale forhold, kan styrke mistanken ytterligere (tab 1) (5-7). Det er imidlertid ikke alltid lett å fange opp anfall under EEG-registrering, for eksempel hos pasienter der anfallene kommer sjelden. Derfor kan sikker diagnose i noen tilfeller først stilles etter observasjon over lengre tid (opptil flere måneder eller år). At 10-30\% av dem som har epilepsi også har psykogene ikke-epileptiske anfall, kompliserer diagnostikken ytterligere (8).

\section{Hvordan formidle diagnosen?}

Formidling av diagnosen må skje på en respektfull og empatisk måte. Hvordan formidlingen skjer, har vist seg å være av betydning for prognosen og mestring av tilstanden $(9,10)$. Studier der det gis anbefalinger for hvordan man bør ordlegge seg, er oppsummert i retningslinjene for behandling av psykogene ikke-epileptiske anfall (9). Blant annet anbefales det å forklare mekanismer som er involvert i dissosiasjon. Det kan bidra til at pasienten føler seg mer tatt på alvor og at anfallene ikke er simulering $(9,11)$.

Grundig informasjon om hvordan slike anfall kan oppstå, kan i noen tilfeller bidra til at de forsvinner (12). Målet er en felles forståelse av at både biologiske og psykososiale (predisponerende, utløsende og vedlikeholdende) faktorer spiller en rolle. De som ser en mulig sammenheng mellom tidligere livshendelser (samt nåværende livs-

\section{Mia Tuft}

mia.tuft@ous-hf.no

Nasjonalt kompetansesenter for sjeldne

epilepsirelaterte diagnoser

Kvinne- og barneklinikken

Oslo universitetssykehus

\section{Hilde Nordahl Karterud \\ Antonia Villagran}

Karl 0. Nakken

Spesialsykehuset for epilepsi, SSE

Klinikk for kirurgi og nevrofag

Oslo universitetssykehus

Engelsk oversettelse på www.tidsskriftet.no

\section{HOVEDBUDSKAP}

Psykogene ikke-epileptiske anfall er ofte ledd i dissosiative eller somatoforme lidelser

Diagnostikken kan være vanskelig, og anfallsregistreringer med video-EEG er ofte nødvendig

Formidlingen av diagnosen og et tett samarbeid mellom nevrologien og psykiatrien er viktig for prognosen

Hos personer med slike anfall har vi foreløpig best erfaring med psykoterapeutisk oppfølging 
Tabell 1 Noen forskjeller mellom epileptiske tonisk-kloniske anfall og psykogene ikke-epileptiske anfall (5-7)

\begin{tabular}{|c|c|c|}
\hline & $\begin{array}{l}\text { Epileptiske } \\
\text { tonisk-kloniske anfall }\end{array}$ & $\begin{array}{l}\text { Psykogene } \\
\text { ikke-epileptiske anfall }\end{array}$ \\
\hline Alder & Alle aldre & Hovedsakelig 15-35 års alder \\
\hline Kjønn & Begge kjønn & Hovedsakelig kvinner (70-80\%) \\
\hline $\begin{array}{l}\text { Forekomst under våkenhet/ } \\
\text { søvn }\end{array}$ & Både under våkenhet og søvn & I våken tilstand \\
\hline Anfallsstart & Brå & Ofte gradvis \\
\hline Anfallsvarighet & Som oftest $<2$ minutter & Ofte $>5$ minutter \\
\hline Øyne & Åpne & Som oftest lukket \\
\hline Motorisk aktivitet & Symmetriske rykninger & $\begin{array}{l}\text { Som oftest asymmetriske } \\
\text { bevegelser }\end{array}$ \\
\hline Tungebitt & Ofte & Sjelden, kan forekomme \\
\hline Verbal respons & Aldri & Noen ganger \\
\hline Postiktal tilstand & Forvirring, døsighet & Som oftest klar, våken \\
\hline Amnesi & Alltid & Varierende \\
\hline
\end{tabular}

situasjon) og anfallene, har lettere for å akseptere diagnosen og er mer mottakelig for videre behandlingstilbud (11).

Ettersom diagnostiseringen skjer i nevrologien, er formidlingen av anfallenes natur som regel nevrologens oppgave. Mange nevrologer kan finne det vanskelig å forklare pasienten om årsakssammenhenger ved psykogene ikke-epileptiske anfall. Likeså kan det være vanskelig å fortelle at behandlingen skal finne sted innen psykisk helsevern $(9,13)$.

I motsetning til pasientene forstår mange nevrologer tilstanden som et «rent psykologisk problem» (14). Pasienter med psykogene ikke-epileptiske anfall har som regel hatt flere negative livshendelser enn pasienter med epilepsi. Likevel har de som oftest vanskelig for å se en sammenheng mellom slike hendelser og anfallene. Dersom nevrologen insisterer på at symptomene har «psykiske» årsaker, kan pasienten reagere med motstand mot diagnosen (13). Etter vår kliniske erfaring er det lettere for pasienten å forstå psykogene ikke-epileptiske anfall jo tryggere legen er i situasjonen med å forklare somatoforme symptomer.

\section{Behandling}

\section{Psykoedukasjon}

Selv om behovet for behandling varierer, bør alle få tilbud om psykoedukasjon, det vil si en behandling tuftet på pedagogiske prinsipper (15). Ved spesialsykehuset for epilepsi ved Oslo universitetssykehus får nydiagnostiserte tilbud om oppfølging som inneholder psykoedukative elementer, indi- viduelt eller i grupper. De får økt kunnskap om diagnosen og praktisk veiledning $i$ anfallshåndtering.

Pasienter fra hele landet kan henvises. Det er per i dag noen måneders ventetid. Norsk Epilepsiforbund inkluderer personer med psykogene ikke-epileptiske anfall i sin organisasjon. Her kan man treffe andre med samme diagnose og dermed få økt innsikt i tilstanden.

\section{Videre behandling}

De fleste med psykogene ikke-epileptiske anfall vil være i behov av behandling innenfor psykisk helsevern (9). Man bør derfor raskt etablere kontakt med det lokale hjelpeapparatet. Oppfølgende behandling bør skje ved lokale barne- og ungdomspsykiatriske sentre, distriktspsykiatriske sentre eller hos privatpraktiserende psykiatere eller psykologer. Noen pasienter, særlig de med både epileptiske anfall og psykogene ikke-epileptiske anfall, bør i tillegg ha videre oppfølging fra nevrolog.

Det er viktig å unngå at pasienten blir en kasteball mellom nevrologien og psykiatrien. Særlig bør man unngå gjentatte runder med ikke-indiserte utredninger eller behandlingsforsøk. Ved oppstart av behandling bør man sørge for:

- Psykiatrisk vurdering. En grundig psykiatrisk vurdering vil kunne avdekke en eventuell underliggende psykiatrisk diagnose. Dessuten vil en slik vurdering kunne utelukke psykiatriske differensialdiagnoser, som for eksempel panikkangst, eventuelt si noe om psykiatrisk komorbiditet samt indikasjon for behandling

- Kartlegging av predisponerende, utløsende og opprettholdende mekanismer

I likhet med genuine epileptiske anfall oppfattes psykogene ikke-epileptiske anfall som et symptom, ikke som en sykdom. $\AA$ kartlegge predisponerende, utløsende og opprettholdende faktorer kan bidra til en bedre forståelse av patofysiologiske mekanismer og er vesentlig for å iverksette en skreddersydd behandling.

En kvinnelig pasient kan tjene som eksempel: Hun har en historie med overgrep i barndommen og dessuten en alvorlig somatisk sykdom (presdiponerende faktorer). Hun får sitt første anfall rett etter en operasjon (utløsende faktor). Manglende diagnose og en stadig vanskeligere livssituasjon, hvor hun trekker seg mer og mer tilbake på grunn av angst for anfall, forsterker anfallstendensen (vedlikeholdende faktorer).

Etter vår erfaring kan en anfallskalender være et nyttig verktøy i arbeidet med å sette ord på hva som skjer med kropp og følelsesliv før, under og etter et anfall. De som har slike anfall, oppmuntres derfor til å føre en anfallskalender og bruke denne til å reflektere over sin situasjon sammen med terapeuten.

\section{Psykoterapi}

Det finnes ingen studier som viser at én behandlingsmetode er bedre enn en annen for denne pasientgruppen. Kognitiv atferdsterapi er den metoden som er mest i bruk, men også psykodynamiske modeller blir benyttet (9).

Dersom dysfunksjonelle familieforhold er en utløsende og/eller opprettholdende faktor, bør hele familien involveres $\mathrm{i}$ behandlingen (9). Med noe kunnskap om psykogene ikkeepileptiske anfall og om dissosiative og somatoforme lidelser vil de fleste psykologer og psykiatere ha gode forutsetninger for å behandle personer med slike anfall.

\section{Farmakologisk behandling}

Hos dem som bruker antiepileptika, bør disse trappes langsomt ned til full seponering i forståelse med pasienten. Hos pasienter med både psykogene ikke-epileptiske anfall og epilepsi bør man vurdere dosereduksjon og helst bruk av monoterapi, hvis mulig. Det finnes ingen farmakologisk behandling rettet spesifikt mot psykogene ikke-epileptiske anfall.

\section{Prognose}

Det finnes få studier der man har sett på prognose i relasjon til gitt behandling, men flere studier viser at omtrent to tredeler fremdeles har en del anfall 3-6 måneder etter at dia- 
gnosen er stilt (9). Prognosen er bedre hos barn enn hos voksne (16).

Som ved epilepsi er anfallsfrihet hovedmålet med behandlingen. Symptomlette i form av høyere livskvalitet og mindre psykiske vansker er imidlertid også viktige behandlingsmål (10). Trygg anfallshåndtering samt det å unngå akutt medisinering og akutte sykehusinnleggelser kan redusere risikoen for iatrogene skader.

\section{Bilkjøring}

Leger som behandler personer med anfallslidelser bør kjenne til lovverket for bilkjøring. En person med psykogene ikkeepileptiske anfall med påvirket bevissthet fyller ikke de helsemessige krav til å inneha førerkort. For å få tilbake, eventuelt kvalifisere for førerkort, må man ha vært anfallsfri i ett år.

Hos dem som har anfall uten påvirket bevissthet, må behandlende lege vurdere om det er forsvarlig at vedkommende kjører bil.

\section{Konklusjon}

For å gi pasienter med psykogene ikke-epileptiske anfall god behandling, kreves tid, kompentanse og tett samarbeid mellom nevrologien og psykiatrien. Som ellers $i$ medisinen hviler en vellykket behandling på korrekt diagnose. Å formidle diagnosen på en respektfull og empatisk måte har betydning for prognosen.

Fordi pasientgruppen er svært heterogen, må behandlingen individualiseres. Psykoterapi anses $\mathrm{i}$ dag som den best validerte behandlingen.

\section{Mia Tuft (f. 1972)}

er spesialist i nevropsykologi. Hun har skrevet barnebøker om å leve med epilepsi.

Forfatter har fylt ut ICMJE-skjemaet og oppgir ingen interessekonflikter.

\section{Hilde Nordahl Karterud (f. 1956)}

er ph.d-student.

Forfatter har fylt ut ICMJE-skjemaet og oppgir ingen interessekonflikter.

\section{Antonia Villagran (f. 1976)}

er spesialist i nevrologi, med spesialkompetanse i epileptologi, og overlege.

Forfatter har fylt ut ICMJE-skjemaet og oppgir ingen interessekonflikter.

\section{Karl O. Nakken (f. 1945)}

er spesialist i nevrologi, med spesialkompetanse i epileptologi, og medisinsk sjef.

Forfatter har fylt ut ICMJE-skjemaet og oppgir ingen interessekonflikter.

\section{Litteratur}

1. Lund C, Haraldsen I, Lossius MI et al. Psykogene ikke-epileptiske anfall. Tidsskr Nor Legeforen 2009; 129: 2348-51.

2. Reuber M. The etiology of psychogenic non-epileptic seizures: toward a biopsychosocial model. Neurol Clin 2009; 27: 909-24.

3. Benbadis SR. Psychogenic non-epileptic seizures. I: Wyllie E, red. The treatment of epilepsy: principles and practice. Philadelphia, PE: Lippincott, Williams \& Wilkins, 2005: 623-30.

4. Reuber M, Fernández G, Bauer J et al. Diagnostic delay in psychogenic nonepileptic seizures. Neurology 2002; 58: 493-5.

5. Brodtkorb E. Common imitators of epilepsy. Acta Neurol Scand Suppl 2013; 127: 5-10.
6. Duncan R. Psychogenic nonepileptic seizures: diagnosis and initial management. Expert Rev Neurother 2010; 10: 1803-9.

7. Reuber M, Mayor R. Recent progress in the understanding and treatment of nonepileptic seizures. Curr Opin Psychiatry 2012; 25: 244-50.

8. Benbadis SR, Agrawal V. Tatum WO. How many patients with psychogenic nonepileptic seizures also have epilepsy? Neurology 2001; 57: 915-7.

9. LaFrance WC Jr, Reuber M, Goldstein LH. Management of psychogenic nonepileptic seizures. Epilepsia 2013; 54 (suppl 1): 53-67.

10. Bodde NM, Janssen AM, Theuns $C$ et al. Factors involved in the long-term prognosis of psychogenic nonepileptic seizures. J Psychosom Res 2007; 62: 545-51.

11. Karterud HN, Risør MB, Haavet OR. The impact of conveying the diagnosis when using a biopsychosocial approach: A qualitative study among adolescents and young adults with NES (nonepileptic seizures). Seizure 2015; 24: 107-13.

12. McKenzie P, Oto M, Russell A et al. Early outcomes and predictors in 260 patients with psychogenic nonepileptic attacks. Neurology 2010; 74: 64-9.

13. Monzoni CM, Duncan R, Grünewald R et al. Are there interactional reasons why doctors may find it hard to tell patients that their physical symptoms may have emotional causes? A conversation analytic study in neurology outpatients. Patient Educ Couns 2011: 85: e189-200.

14. Whitehead K, Reuber M. Illness perceptions of neurologists and psychiatrists in relation to epilepsy and nonepileptic attack disorder. Seizure 2012; 21: 104-9.

15. Mayor R, Brown RJ, Cock H et al. A feasibility study of a brief psycho-educational intervention for psychogenic nonepileptic seizures. Seizure 2013; 22: 760-5.

16. Reuber M, Pukrop R, Bauer J et al. Outcome in psychogenic nonepileptic seizures: 1 to 10 -year follow-up in 164 patients. Ann Neurol 2003; 53: $305-11$.

Mottatt 6.11. 2014, første revisjon innsendt 28.4 . 2015, godkjent 10.6. 2015. Redaktør: Tor Rosness. 